\title{
Industrial Wastewater Monitoring in the Public Health Institutions in Serbia
}

\author{
BRANISLAVA I. MATIĆ, Institute of Public Health of Serbia \\ „Dr Milan Jovanović Batut“ Belgrade \\ SNEŽANA M. ĐURANOVIĆ, Institute of Public Health of Serbia \\ „Dr Milan Jovanović Batut", Belgrade \\ KATARINA R. SPASOVIĆ, Institute of Public Health of Serbia \\ „Dr Milan Jovanović Batut“, Belgrade \\ MILJAN V. RANCIIĆ, Institute of Public Health of Serbia \\ „Dr Milan Jovanović Batut“, Belgrade
}

\author{
Original scientific paper \\ $U D C: 628.3$ \\ DOI: 10.5937/tehnika1804587M
}

Wastewater disposal is recognized by the public health sector for its potential negative environmental health impact. This paper is a cross-sectional study, for an observational period from 2015-2017, with an aim to present the scope of involvement of public health institutions in monitoring of industrial wastewaters. Wastewaters were sampled from industrial facilities of chemical, food-processing, mining-smelting and energy, transport, service, wood-processinga and textile production origin. As a study tool we used a data-base of the Institute of Public Health of Serbia, being filled-in with data from the local IPHs, analyzing wastewater quality on contract basis. In total, summing results from three consecutive years, 13392 wastewater samples were collected and analyzed, of which 44.79\% (5999) did not comply to the adopted national standards. By observing wastewater treatment dynamics, generating from the legal entities whose samples were analyzed, it appears that it is insufficiently implemented. In all three monitoring years treatment persisted in less than 50\% of facilities, which can be linked to the fact that parameters burdening samples at its most are: suspended and sediment matter, chemical oxygen demand, biological oxygen demand, ammonia, fats and oils, etc. The fact that most of the effluents are disposed of directly into natural watercourses indicates the constantly present risk for both environment and health.

Key words: industrial wastewater, samples, institutes of public health, treatment

\section{INTRODUCTION}

Industrial wastewaters are among most significant sources of environmental pollution, in general, with special harm done to the natural water bodies. Negative effect of the effluents to aquatic systems and human organism, originating from present hazardous substances; have been noted at both national and international levels. Some of the effects include death of live organisms in the aquatoria, algal bloom, destruction and devastation of natural habitats through their exposure to toxic sediment matter, disposed waste, together with other effects of long-term effect

Author's address: Branislava Matić, Institute of Public Health of Serbia, „Dr Milan Jovanović Batut“ Belgrade, Dr Subotića - Starijeg 5

e-mail: damjanko98@yahoo.com

Paper received: 01.02.2018.

Paper accepted: 20.02.2018. on the environment of toxicants. Chemicals' accumulation and magnification, together with their entering into food chain presents a potential public health risk [1]

Irregular wastewater disposal has been a global problem for the environmental status, ever since. According to their origin and structure, the polluting substances of our concern are grouped in two fractions: biological and chemical [2]. Pollutants of key importance for the wastewater quality are nitrogen, phosphorus, heavy metals, detergents, pesticides and hydrocarbons [3].

Contents of wastewater vary significantly according to their origin, especially in the case of industrially contaminated ones. Thus, defining unique parameters for all kinds of wastewater is aggravated, due to this reason. Some key parameters are chosen as indicators of both chemical and biological pollution and processes undergoing in this environmental me- 
dium: color, turbidity, biological oxygen demand (BOD), chemical oxygen demand (COD), pH, dry matter, suspended matter, heavy metals, nutrients nitrogen and phosphorus, toxic substances [4].

Law on Public Health regulates realization of public interests, together with generating conditions for the upgrading of the health status of general population, through comprehensive societal activities focused on preserving its physical and mental health, preservation of the living and occupational environment, prevention of the generation and harmful effects of the risk factors essential for the occurrence of disease, trauma. This Law also regulates means and procedures, together with the conditions needed for the organization and implementation of public health measures and processes [5]. Public health institutions in the Republic of Serbia are distributed according to the Decree on the Network of Healthcare Facilities [6], within the official network of 25 Institutes of Public Health (IPHs), topped by the Institute of Public Health of Serbia (IPHS) "Dr Milan Jovanović Batut", as a beacon of public health in the country. Spatial distribution of the IPHs Network is presented in Figure 1.

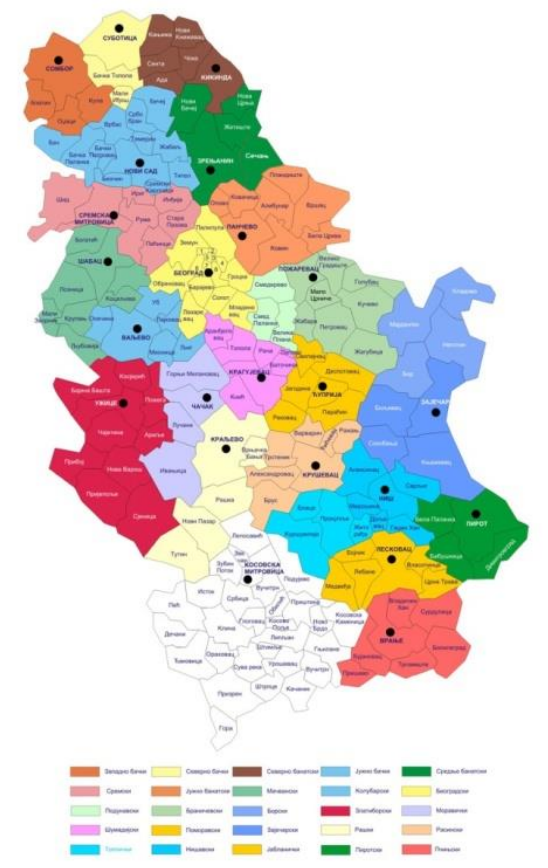

Figure 1 - Network of IPHs in Serbia

Activities undertaken within their territorial jurisdiction by the IPHs are in accordance with the Law on Health Protection, especially its section implying to social care for the health of the population (art.8), which ensures preservation and improvement of health through monitoring and suppression of risk factors, acquiring of knowledge and habits essential for health and wellbeing. Article 10 of the same Law, defines activities of IPHs in the field of protecting vulnerable population groups and general population from harmful effects of toxic substances originating in polluted water, air, soil and incorrectly dumped and deposited waste. Protection from both ionized and non-ionized radiation is also defined by this Law [7].

Key objective of this manuscript is to present the level of involvement of public health institutions in the process of industrial wastewater monitoring, focusing on the components of wastewaters mostly burdening their final recipient, with a potential to provoke a long-term public health threat.

\section{METHODS AND DATA COLLECTION}

Manuscript is based on the results of a crosssectional study, with a 3-year time frame (20152017). Wastewater samples tested in the IPHs' labs in Serbia originate from industrial facilities (processes). Physico-chemical and microbiological parameters were tested by using standard methods, in accordance with currently applicable regulations [8-11]. Industrial facilities generating wastewater that was tested in this study, belong to the following industrial branches: chemical, food production and processing, metal-processing, transport, services, wood-processing and textile production.

As a research tool a data-base designed by the National IPH was used. Such was regularly updated on an annual basis, collating data from those IPHs having sufficient technical capacities for performing lab test of wastewater samples, mostly from facilities atwithin the boundaries of their territorial jurisdiction. This data-base was formed in 2005 . We used the data from the regular Annual Reports on the Industrial Wastewater Quality produced by the National IPH, for the given monitoring period $(2015,2016,2017)$ [12-14]. As the aim of this manuscript is to give an insight into the industrial wastewater monitoring in the network of IPHs in Serbia, the following elements shall be presented: number of industrial facilities whose wastewater samples have been analyzed, number samples, number of non-compliant samples, wastewater treatment reperesentation among the mentioned facilities, according to the industrial branch.

\section{RESULTS}

Table 1 presents distribution of samples by its number and IPH where laboratories are seated, together with the number of industrial facilities generating them. Samples were analyzed in 23 IPHs labs, excluding IPH Sremska Mitrovica and Novi Pazar, without technical capacities to perform such activities.

Concerning the number of industrial facilities generating the given wastewater samples, a continu- 
ous decrease is noted for all 3 years in a row: 4660 in 2015, 4445 in 2016 and 4287 in 2017. Mean percentage value for non-compliant samples is beyond $40 \%$ for all reporting years, with a slight increasing tendency observed.

The IPHs having the largest number of contracts with industrial facilities for sample analyses were seated in Subotica, Užice, Šabac and Kruševac; while the most of individual samples were analyzed in labs of the following IPHs: Ćuprija, Subotica and Požarevac.

IPHs with the largest number of wastewater samples non-compliant to the Decree are in Kikinda, Valjevo and Niš, regardless the fact that their labs, actually, have not received the largest number of samples, when compared to the other IPHs

Table 1. Distribution of samples by its number and IPH where laboratories are seated in 2015-2017

\begin{tabular}{|c|c|c|c|c|c|c|c|c|c|c|c|c|}
\hline \multirow[t]{2}{*}{ IPH seat } & \multicolumn{3}{|c|}{$\begin{array}{l}\text { Industrial facilities } \\
(\mathrm{N})\end{array}$} & \multicolumn{3}{|c|}{$\begin{array}{l}\text { Total number of waste } \\
\text { water samples }\end{array}$} & \multicolumn{3}{|c|}{$\begin{array}{l}\text { Number of non- } \\
\text { compliant samples }\end{array}$} & \multicolumn{3}{|c|}{$\begin{array}{l}\% \text { of non-compliant } \\
\text { samples }\end{array}$} \\
\hline & 2015 & 2016 & 2017 & 2015 & 2016 & 2017 & 2015 & 2016 & 2017 & 2015 & 2016 & 2017 \\
\hline Subotica & 77 & 67 & 64 & 334 & 391 & 374 & 173 & 175 & 185 & 51.8 & 44.76 & 49.46 \\
\hline Zrenjanin & 24 & 20 & 19 & 121 & 108 & 101 & 66 & 59 & 55 & 54.54 & 54.63 & 54.46 \\
\hline Kikinda & 50 & 50 & 47 & 41 & 45 & 31 & 37 & 30 & 27 & 90.24 & 66.67 & 87.10 \\
\hline Pančevo & 10 & 12 & 12 & 45 & 103 & 65 & 37 & 64 & 53 & 82.22 & 62.13 & 81.54 \\
\hline Sombor & 19 & 20 & 14 & 185 & 207 & 114 & 75 & 76 & 70 & 40.54 & 36.71 & 61.40 \\
\hline IPH Vojvodina & 49 & 47 & 39 & 207 & 208 & 166 & 120 & 116 & 75 & 57.97 & 55.77 & 45.18 \\
\hline Beograd & 14 & 14 & 14 & 130 & 167 & 143 & 7 & 35 & 42 & 5.38 & 20.96 & 29.37 \\
\hline Šabac & 60 & 59 & 79 & 145 & 162 & 233 & 81 & 71 & 102 & 55.86 & 43.83 & 43.78 \\
\hline Valjevo & 26 & 18 & 17 & 41 & 26 & 26 & 11 & 21 & 19 & 26.83 & 30.77 & 73.08 \\
\hline Požarevac & 77 & 76 & 83 & 307 & 223 & 356 & 150 & 120 & 207 & 48.86 & 53.81 & 58.15 \\
\hline IPH Kragujevac & 49 & 44 & 44 & 210 & 200 & 223 & 66 & 139 & 140 & 31.43 & 69.5 & 62.78 \\
\hline Ćuprija & 19 & 19 & 33 & 838 & 646 & 419 & 372 & 287 & 356 & 44.4 & 44.43 & 84.96 \\
\hline Zaječar & 45 & 40 & 53 & 196 & 223 & 226 & 45 & 44 & 80 & 22.96 & 19.73 & 35.40 \\
\hline Užice & 95 & 81 & 91 & 279 & 262 & 308 & 133 & 114 & 137 & 47.67 & 43.51 & 44.48 \\
\hline Čačak & 105 & 45 & 46 & 213 & 205 & 213 & 66 & 58 & 64 & 30.99 & 28.29 & 30.05 \\
\hline Kraljevo & 39 & 46 & 64 & 188 & 241 & 281 & 67 & 65 & 87 & 35.64 & 26.97 & 30.96 \\
\hline Kruševac & 87 & 88 & 79 & 387 & 314 & 290 & 72 & 116 & 89 & 18.6 & 36.94 & 30.69 \\
\hline IPH Niš & 63 & 54 & 54 & 253 & 274 & 350 & 166 & 176 & 209 & 65.61 & 64.23 & 59.71 \\
\hline Pirot & 7 & 9 & 11 & 9 & 50 & 36 & 0 & 16 & 7 & 0 & 24.24 & 19.44 \\
\hline Leskovac & 42 & 53 & 52 & 196 & 143 & 154 & 68 & 54 & 60 & 34.69 & 37.76 & 38.96 \\
\hline Vranje & 45 & 37 & 37 & 263 & 143 & 112 & 99 & 42 & 26 & 37.64 & 24.37 & 23.21 \\
\hline KM & 15 & 15 & 15 & 15 & 15 & 15 & 7 & 9 & 7 & 46.66 & 60.0 & 46.67 \\
\hline IPHS "Batut" & 21 & 19 & 12 & 57 & 89 & 51 & 22 & 48 & 27 & 39.0 & 53.93 & 52.94 \\
\hline Total & 1038 & 933 & 979 & 4660 & 4445 & 4287 & 1940 & 1935 & 2124 & 41.63 & 43.53 & 49.54 \\
\hline
\end{tabular}

Table 2. Distribution of facilities by type of industry and number of IPHs analyzing samples

\begin{tabular}{|l|l|l|l|l|l|l|}
\hline Industrial branch & 2015 & 2016 & 2017 \\
\hline & $\begin{array}{l}\text { No of } \\
\text { facilities }\end{array}$ & $\begin{array}{l}\text { No of } \\
\text { IPHs }\end{array}$ & $\begin{array}{l}\text { No of } \\
\text { facilities }\end{array}$ & $\begin{array}{l}\text { No of } \\
\text { IPHs }\end{array}$ & $\begin{array}{l}\text { No of } \\
\text { facilities }\end{array}$ & $\begin{array}{l}\text { No of } \\
\text { IPHs }\end{array}$ \\
\hline Chemicals & 93 & 17 & 74 & 18 & 71 & 19 \\
\hline Energy/ mining & 116 & 18 & 89 & 21 & 96 & 19 \\
\hline Food production & 405 & 23 & 391 & 22 & 407 & 23 \\
\hline Transport & 49 & 16 & 38 & 14 & 46 & 14 \\
\hline Textile & 21 & 11 & 20 & 10 & 24 & 9 \\
\hline Services & 291 & 23 & 248 & 23 & 266 & 22 \\
\hline Wood/furniture & 19 & 6 & 16 & 6 & 15 & 6 \\
\hline Other & 42 & 10 & 57 & 12 & 54 & 9 \\
\hline Total & $\mathbf{1 0 3 6}$ & & $\mathbf{9 3 3}$ & & $\mathbf{9 7 9}$ & \\
\hline
\end{tabular}


Table 2 shows Distribution of facilities by type of industry and number of IPHs analyzing samples. In the case of food industry, dominating with the number of wastewater samples in this study $(39.09 \%$ in 2015 ; $41.9 \%$ in $2016 ; 41.57 \%$ in 2017 ), all listed IPHs have had such samples analyzed (23/23), excluding servicing industry wastewater samples (restaurants, hotels) being analyzed by $22 / 23$ laboratories.

\section{WASTEWATER TREATMENT PRIOR TO ITS FINAL DISPOSAL INTO THE RECIPIENT}

From the insight into the available data on the issue of implementation of wastewater treatment prior to its disposal to the final recipient (centralized sewage system, natural watercourses, pit latrines), by the industrial facilities (Table 3 ), in all 3 consecutive years (2015-2017), more than half of them do not treat the wastewater.

Namely, inexistence of wastewater treatment was registered accordingly: in year $2015-57.22 \%$; in year $2016-50.66 \%$ and in $2017-56.91 \%$.

Further on, we emphasize the importance of results for the year 2017. Among the given industries whose facilities participated with wastewater samples, only in the case of chemical and textile industries less than $50 \%$ of them (cca $40 \%$ ) performed no pre-treatment of their effluents.

The least treated wastewaters in 2017 were those from the wood/furniture and food industry.

Table 3. Wastewater treatment by type of industry - in total

\begin{tabular}{|c|c|c|c|c|c|c|}
\hline \multirow{3}{*}{$\begin{array}{l}\text { Industrial branch / } \\
\text { facilities }\end{array}$} & \multicolumn{2}{|l|}{2015} & \multicolumn{2}{|l|}{2016} & \multicolumn{2}{|l|}{2017} \\
\hline & \multicolumn{2}{|c|}{ Treatment } & \multicolumn{2}{|c|}{ Treatment } & \multicolumn{2}{|c|}{ Treatment } \\
\hline & yes & no & yes & no & yes & no \\
\hline Chemicals & 43 & 48 & 43 & 30 & 42 & 28 \\
\hline Energy/mining & 49 & 61 & 43 & 46 & 44 & 52 \\
\hline Food production & 149 & 231 & 148 & 237 & 154 & 252 \\
\hline Transport & 28 & 18 & 19 & 17 & 19 & 27 \\
\hline Textile & 7 & 13 & 9 & 11 & 14 & 10 \\
\hline Services & 126 & 155 & 108 & 138 & 122 & 144 \\
\hline Wood /furniture & 4 & 13 & 8 & 7 & 4 & 11 \\
\hline Other & 420 & 566 & 19 & 33 & 22 & 32 \\
\hline Total & 826 & 1105 & 397 & 519 & 421 & 556 \\
\hline Total (\%) & 42,78 & 57.22 & 43.34 & 50.66 & 43.09 & 56.91 \\
\hline
\end{tabular}

We specifically focused our attention to facilities not having installed a wastewater treatment system, at all. Of the total number of facilities participating in wastewater sampling in 2017 (979), such were 200 industrial facilities $(20.43 \%)$, which should not be ignored [14].

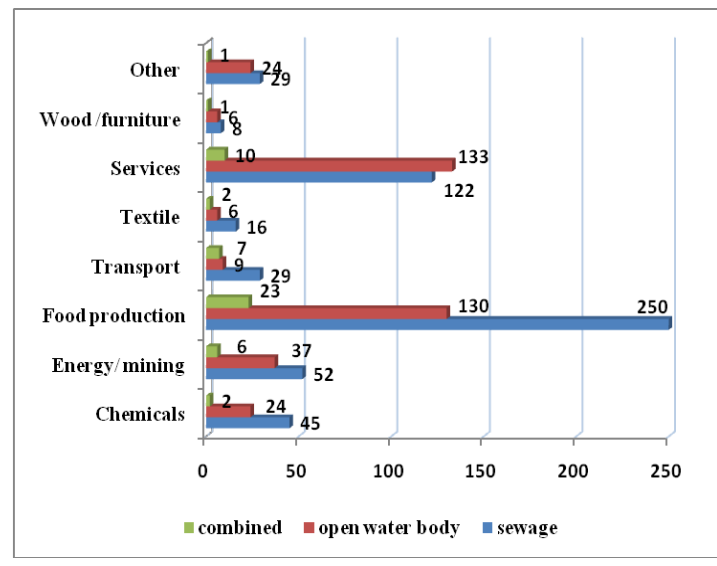

Figure 2 - Distribution of final wastewater disposal
Analysis of the distribution of wastewater final disposal into the recipient, for year 2017 is shown in Figure 2.

The chosen criterion was whether the industrial wastewater is disposed off into the centralized sewage system, natural watercourse (river flow, lake), or a combination of the both.

Actually, more than $50 \%$ of facilities involved in wastewater sampling in 2017, in chosen industrial branches, except services, use centralized sewage system as a final recipient [14].

\section{THE MOST COMMON CAUSE OF THE WASTEWATER SAMPLES' NONCOMPLIANCE TO THE NATIONAL STANDARDS}

In line with the adopted legal acts, parameters which have been analyzed are defined according to the industrial activity of the wastewaters' generators $[9,10]$. 
Table 4. Dominant presence of certain parameters in wastewater samples tested in the period 2015-2017

\begin{tabular}{|c|c|c|c|}
\hline IPH seat/year & 2015 & 2016 & 2017 \\
\hline Subotica & $\begin{array}{l}\text { SM, COD, BOD, TN, TP, } \\
\mathrm{pH}\end{array}$ & $\begin{array}{l}\mathrm{SM}, \mathrm{COD}, \mathrm{BOD}, \mathrm{TN}, \mathrm{TP}, \\
\mathrm{pH}\end{array}$ & $\begin{array}{l}\mathrm{SM}, \mathrm{COD}, \mathrm{BOD}, \mathrm{TN}, \mathrm{TP}, \\
\mathrm{pH}, \mathrm{NH}_{3}\end{array}$ \\
\hline Zrenjanin & $\mathrm{SM}, \mathrm{COD}, \mathrm{BOD}, \mathrm{TP}$ & $\mathrm{SM}, \mathrm{COD}, \mathrm{BOD}, \mathrm{TP}$ & $\begin{array}{l}\text { SM, COD, BOD, TN, TP, } \\
\text { MB }\end{array}$ \\
\hline Kikinda & $\begin{array}{l}\mathrm{COD}, \mathrm{BOD}, \mathrm{TN}, \mathrm{TP}, \mathrm{NH}_{3}, \\
\mathrm{MB} \text { (Colif. bact., Strept. } \\
\text { foecalis) }\end{array}$ & $\begin{array}{l}\mathrm{COD}, \mathrm{BOD}, \mathrm{TN}, \mathrm{TP}, \mathrm{NH}_{3}, \\
\mathrm{MB} \text { (Colif. bact., Streptoc. } \\
\text { foecalis) }\end{array}$ & $\begin{array}{l}\mathrm{COD}, \mathrm{BOD}, \mathrm{TN}, \mathrm{TP}, \mathrm{MB}, \\
\mathrm{NH}_{3}\end{array}$ \\
\hline Pančevo & $\begin{array}{l}\text { SM, COD, TP, BOD, TN, } \\
\text { fats/oils }\end{array}$ & $\begin{array}{l}\text { SM, COD, TP, BOD, TN, } \\
\text { fats/oils }\end{array}$ & $\begin{array}{l}\mathrm{SM}, \mathrm{COD}, \mathrm{TP}, \mathrm{BOD}, \mathrm{TN}, \\
\mathrm{NH}_{3}, \mathrm{MB}\end{array}$ \\
\hline Sombor & SM, COD, BOD & $\mathrm{SM}, \mathrm{COD}, \mathrm{BOD}$ & SM, COD, BOD \\
\hline Novi Sad & SM, COD, BOD, TN, TP & SM, COD, BOD, TN, TP & SM, COD, BOD, TN, TP \\
\hline Beograd & Chemical burden & Chemical burden & Chemical burden \\
\hline Šabac & Organic matter & Organic matter & Organic matter, oils \\
\hline Valjevo & $\begin{array}{l}\mathrm{SM}, \mathrm{COD}, \mathrm{BOD}, \mathrm{NH}_{3}, \\
\mathrm{NO}_{3}^{-}, \mathrm{NO}_{2}^{-} \text {, fats/ oils, } \\
\mathrm{TPO}_{4}, \mathrm{MB}\end{array}$ & $\begin{array}{l}\mathrm{SM}, \mathrm{COD}, \mathrm{BOD}, \mathrm{NH}_{3}, \mathrm{NO}_{2}^{-} \\
\text {, fats/ oils, } \mathrm{Fe}, \mathrm{MB}\end{array}$ & $\begin{array}{l}\mathrm{SM}, \mathrm{COD}, \mathrm{BOD}^{\mathrm{NH}} 3 \text {, fats/ } \\
\text { oils, } \mathrm{MB}, \mathrm{TPO}_{4}^{-}\end{array}$ \\
\hline Požarevac & $\begin{array}{l}\mathrm{NH}_{4}^{+}, \mathrm{SM}, \mathrm{COD}, \mathrm{BOD}, \\
\mathrm{TPO}_{4}\end{array}$ & $\begin{array}{l}\mathrm{NH}_{4}{ }^{+}, \mathrm{SM}, \mathrm{BOD}, \mathrm{COD}, \mathrm{O}_{2}, \\
\mathrm{Cr}, \mathrm{Sn}, \mathrm{Zn}\end{array}$ & $\begin{array}{l}\mathrm{NH}_{4}^{+}, \mathrm{SM}, \mathrm{COD}, \mathrm{BOD}, \\
\mathrm{TPO}_{4}\end{array}$ \\
\hline Kragujevac & $\begin{array}{l}\mathrm{MB}, \mathrm{TPO}_{4}^{-}, \mathrm{SM}, \mathrm{BOD}, \\
\text { sediment matter, } \mathrm{NH}_{3}, \\
\text { COD, fats/oils, pH }\end{array}$ & $\begin{array}{l}\mathrm{MB}, \mathrm{TPO}_{4}^{-} \text {, sed.mat, BOD, } \\
\text { fats/oils }\end{array}$ & $\begin{array}{l}\mathrm{MB}, \mathrm{TPO}_{4}^{-}, \mathrm{SM}, \mathrm{BOD}, \mathrm{COD}, \\
\text { sediment matter, fats/oils, } \mathrm{pH}\end{array}$ \\
\hline Ćuprija & $\begin{array}{l}\mathrm{COD}, \mathrm{BOD}, \mathrm{SM}, \mathrm{NO}_{2}^{-}, \\
\mathrm{NH}_{3}\end{array}$ & $\begin{array}{l}\mathrm{COD}, \mathrm{BPK}_{5}, \mathrm{TN}, \mathrm{TP}, \\
\mathrm{NH}_{3}, \mathrm{SM}, \mathrm{MB}\end{array}$ & $\mathrm{COD}, \mathrm{BOD}, \mathrm{SM}, \mathrm{NO}_{2}^{-}, \mathrm{NH}_{3}$ \\
\hline Zaječar & $\mathrm{NH}_{4}^{+}, \mathrm{SM}, \mathrm{pH}, \mathrm{BOD}$ & $\begin{array}{l}\mathrm{NH}_{4}^{+}, \mathrm{SM}, \mathrm{pH}, \mathrm{BOD}, \mathrm{pH}, \\
\mathrm{As}, \mathrm{Cu} \text {, fats/oils }\end{array}$ & $\begin{array}{l}\mathrm{NH}_{4}^{+}, \mathrm{SM} \text {, fats/oils, sediment } \\
\text { matter }\end{array}$ \\
\hline Užice & $\mathrm{COD}, \mathrm{BOD}, \mathrm{SM}, \mathrm{MB}$ & COD, BOD, SM, MB & COD, BOD, SM, TN, TP MB \\
\hline Čačak & $\mathrm{COD}, \mathrm{BOD}, \mathrm{SM}$ & $\begin{array}{l}\mathrm{COD}, \mathrm{BOD}, \mathrm{SM}, \mathrm{NH}_{3} \text {, } \\
\text { fats/oils }\end{array}$ & $\begin{array}{l}\mathrm{COD}, \mathrm{BOD}, \mathrm{SM}, \mathrm{NH}_{3} \text {, } \\
\text { fats/oils }\end{array}$ \\
\hline Kraljevo & $\begin{array}{l}\mathrm{NH}_{4}^{+}, \mathrm{SM}, \mathrm{BOD}, \\
\text { o-PO } \mathrm{PO}_{4} \text {, sed.matter, MB }\end{array}$ & $\begin{array}{l}\mathrm{NH}_{4}{ }^{+}, \text {o- } \mathrm{PO}_{4}, \mathrm{MB}, \mathrm{BOD}, \\
\mathrm{SM} \text {, sediment matter }\end{array}$ & $\begin{array}{l}\mathrm{NH}_{4}{ }^{+}, \text {o- } \mathrm{PO}_{4}, \mathrm{MB}, \mathrm{BOD}, \\
\mathrm{SM} \text {, sediment matter }\end{array}$ \\
\hline Kruševac & $\begin{array}{l}\mathrm{pH}, \mathrm{COD}, \mathrm{BOD}, \mathrm{SM}, \mathrm{Cl}, \\
\mathrm{SO}_{4}^{-2}, \mathrm{NH}_{3}, \mathrm{TN}, \mathrm{TP}, \\
\text { fats/oils }\end{array}$ & $\begin{array}{l}\mathrm{pH}, \mathrm{COD}, \mathrm{BOD}, \mathrm{SM}, \mathrm{Cl}^{-} \\
\mathrm{SO}_{4}^{-2}, \mathrm{NH}_{3}, \mathrm{TN}, \mathrm{TP}, \text { fats/oils }\end{array}$ & $\begin{array}{l}\mathrm{pH}, \mathrm{COD}, \mathrm{BOD}, \mathrm{SM}, \mathrm{Cl}^{-} \\
\mathrm{SO}_{4}^{-2}, \mathrm{NH}_{3}, \mathrm{TN}, \mathrm{TP}, \text { fats/oils }\end{array}$ \\
\hline Nis & Chemical burden & Chemical burden & Chemical burden \\
\hline Pirot & I & $\mathrm{MB}$, fats/oils, $\mathrm{pH}$ & $\begin{array}{l}\mathrm{COD}, \mathrm{BOD}, \mathrm{SM}, \mathrm{SO}_{4}{ }^{-2}, \\
\text { sed.matter, fats/oils, } \mathrm{pH}\end{array}$ \\
\hline Leskovac & $\begin{array}{l}\text { COD, BOD, SM, nutrients, } \\
\mathrm{pH}\end{array}$ & $\mathrm{COD}, \mathrm{BOD}, \mathrm{SM}, \mathrm{Cl}^{-}, \mathrm{pH}$ & $\begin{array}{l}\text { COD, BOD, SM, TN, TP, } \\
\text { sed.matter }\end{array}$ \\
\hline Vranje & $\begin{array}{l}\mathrm{BOD}, \mathrm{COD}, \mathrm{SM}, \mathrm{H}_{2} \mathrm{~S}, \\
\downarrow \text { soluble } \mathrm{O}_{2}, \mathrm{NH}_{3}, \mathrm{NO}_{3}^{-}, \\
\mathrm{NO}_{2}^{-}, \text {phenols, detergents }\end{array}$ & $\begin{array}{l}\mathrm{BOD}, \mathrm{COD}, \downarrow \text { soluble } \mathrm{O}_{2}, \\
\mathrm{NH}_{3}, \mathrm{Fe}, \mathrm{H}_{2} \mathrm{~S}, \text { phenols, } \\
\text { detergents }\end{array}$ & $\begin{array}{l}\mathrm{BPK}_{5}, \mathrm{HPK}, \downarrow \text { soluble } \mathrm{O}_{2}, \\
\mathrm{NH}_{3}, \mathrm{Fe}, \mathrm{H}_{2} \mathrm{~S}, \text { phenols, } \\
\text { detergents }\end{array}$ \\
\hline K.Mitrovica & MB (Strept. foecalis) & MB (Strept.foecalis) & MB (Strept.foecalis) \\
\hline IPHS Batut & $\begin{array}{l}\mathrm{pH}, \mathrm{NH}_{4}{ }^{+}, \text {fats/oils, } \mathrm{BOD}, \\
\mathrm{COD}\end{array}$ & $\begin{array}{l}\mathrm{NH}_{4}{ }^{+} \text {, fats/oils, o- } \mathrm{PO}_{4}, \\
\text { BOD, }\end{array}$ & $\begin{array}{l}\mathrm{pH}, \mathrm{NH}_{4}^{+} \text {, fats/oils, BOD, } \\
\mathrm{COD}^{\mathrm{SM}}, \mathrm{TPO}_{4}^{-}\end{array}$ \\
\hline
\end{tabular}

Among parameters of key importance for the assessment of the complexity of potential harmful effect that an effluent can influence the characteristics of the final wastewater recipient, being analyzed in laboratories of the IPHs Network, we chose for this purpose the following: biological oxygen demand

(BOD), chemical oxygen demand (COD), suspended matter (SM), sediment matter, ammonia $\left(\mathrm{NH}_{3}\right)$, total nitrogen (TN), total phosphorus (TP), nitrates $\left(\mathrm{NO}_{2}\right)$, nitrites $\left(\mathrm{NO}_{3}\right)$, metals and metalloids in their elementary form, ortho-phosphates (o- $\left.\mathrm{PO}_{4}\right)$. Samples belonging to food production industry and service activity 
are in majority of cases additionally burdened with fats and oils. Table 4 shows range of the burden of present parameters on the quality of wastewater samples analyzed in IPHs labs, giving an insight into components of industrial wastewater with a potential environmental impact after its final disposal into sewage or surface water bodies, if released without pre-treatment [12-14].

\section{DISCUSSION}

From the preliminary analysis of the results, it is clear that periodical reports on the quality of industrial wastewater, generated by the Network of IPHs, point to numerous problems and bottle-necks in the process of data managing and analysis in the field of industrial wastewater quality monitoring. Primarily, number of wastewater samples analyzed in the IPHs labs is insuficient for any kind of an in-depth analysis, especially in the light of its constant decrease. This situation is sustaining as such, despite the fact that Law on Health Documentation and Records in the Field of Health (Article 26), clearly defines that: „Based on records from Pragraph 2. of this Article, licenced laboratories, competent institutions and other legal entities being involved in monitoring of environmental risk factors are obliged to submit reports to the competent IPH, depending on the territorial jurisdiction." Reporting on the quality of wastewater and surface water is defined in Point 8, of the same Paragraph 2, Article 26 [15].

It is, also, clear that industrial wastewater treatment is poorly implemented, as number of industrial facilities which do not treat their wastewater in all 3 years of continuous monitoring (2015-2017) was beyond 50\%, which can be linked to the fact that parameters that burden samples at its most are: suspended and sediment matter, chemical oxygen demand, biological oxygen demand, ammonia, fats and oils, etc. The fact that most of the effluents are disposed of directly into natural watercourses indicates at the constantly present risk for both environment and health. Preventing the pollution of water supply sources and public health protection through preventing spread of waterborne diseases, are two key reasons for more significant implementation of comprehensive treatment of wastewater generating from various industrial sources $[16,17]$.

Considering the fact that Serbian state is in the process of pre-accession to the $\mathrm{EU}$, with inevitable opening of the Chapter 27, for the broad field of overall environment protection, it is of utmost importance to approach the problem of wastewater management through a series of concrete activities, among which regulating disposal of wastewater from healthcare facilities should also be included. Mentioning this ,industrial“ branch is not unimportant for the issue of this manuscript, as newly adopted regulation take this wastewater type into account as „municipal wastewater“, which it surely is not, due to heavy presence of very diverse toxic substances and microbial agents in them [18].

Public health sector in Serbia, whith its institutional network, should be responsible for the environmental health impact assessment of the exposed population, not only from this kind of environmental pollution. As mentioned above, while interpreting IPHs role in preventing increase of environmental burden of disease, defined by the Law on Health Protection, namely this segment of environmental protection is an excellent example of a multisectoral approach to a public-health issue.

\section{REFERENCES}

[1] Akpor OB. Wastewater Effluent Discharge: Effects and Treatment Processes; 2011 3rd International Conference on Chemical, Biological and Environmental Engineering IPCBEE, Vol 20(2011), IACSIT Press, Singapore http://www.ipcbee.com/vol20/16-ICBEE2011E20001.pdf.

[2] Kris M. 2007. Wastewater pollution in China. Available from http://darwin.bio.uci.edu/sustain/suscoasts/krismin.html

[3] Larsdotter K. Microalgae for phosphorus removal from wastewater in a Nordic climate. A Doctoral Thesis from the School of Biotechnology, Royal Institute of Technology, Stockholm, Sweden, ISBN: 91-7178-288-5, 2006.

[4] Marinović D, Dimitrijević Z, Stojanović M, Nikolić S. Prečišćavanje otpadnih voda Grada Kraljeva, 37. Međunarodni stručno-naučni skup "Vodovod i Kanalizacija 2016", Vrdnik, 11-14.Oktobar 2016. Zbornik radova: 267-275. ISBN 978-86-80067-34-6

[5] Law on Public Health, "Official Gazette of RS", No.15/2016.

[6] Decree on the Plan for the Network of Healthcare Facilities, “Official Gazette of RS”, No. 92/2015.

[7] Law on Health Protection, "Official Gazette of RS", No. $15 / 2016$.

[8] Law on Sanitary Inspection, "Official Gazette of RS”, No. 125/2004.

[9] Decree on emission limit values for polluting substances in waters with a timeframe for their achievement, Official Gazette of RS, No. 67/2011, 48/2012, $1 / 2016$.

[10]Decree on limit values for polluting substances in surface and ground water and sediment with a timeframe for their achievement, "Official Gazette of RS”, No.50/2012. 
[11]By-law on ecological and chemical status parameters of surface water and chemical and quantitative status of groundwater, "Official Gazette of RS”, No.74/2011.

[12]Annual Reports on the Industrial Wastewater Quality and Sanitary Status of Landfills for the Territory of Republic of Serbia in $2015 \mathrm{http}: / / \mathrm{www} . b a-$ tut.org.rs/download/izvestaji/Izvestaj\%20otpadne\% 20vode\%202015.pdf

[13]Annual Reports on the Industrial Wastewater Quality and Sanitary Status of Landfills for the Territory of Republic of Serbia in 2016, http://www.batut.org.rs/download/izvestaji/Izvestaj\%20otpadne $\% 20$ vode\%202016.pdf

[14]Annual Reports on the Industrial Wastewater Quality and Sanitary Status of Landfills for the Territory of Republic of Serbia in 2017 http://www.batut.org.rs/download/izvestaji/Izvestaj\%20otpadne\%20v ode\%202017.pdf
[15]Law on Health Documentation and Records in the Field of Health, "Official Gazette of RS", No. $123 / 2014,106 / 2015$.

[16]WHO Guidelines for the safe use of wastewater, excreta, and greywater. Volume 2, Wastewater in Agriculture. World Health Organization, Geneva, Swizerland ISBN $9241546867 \mathrm{http} / / / \mathrm{www} . w h o .-$ int/water_sanitation_health/wastewater/wwuvol2intr o.pdf

[17]Akpor OB, Muchie M. Environmental and Public Health Implications of Wastewater Quality, African Journal of Biotechnology, Vol.10 (13): 2379-2387, 2011. DOI: 10.5897/AJB10.1797

[18]Matić B, Jovanović V, Jovanović Lj, Šerović R. Insufficient Implementation of Wastewater Disposal and Municipal Waste Recycling in Healthcare Facilities in Serbia. Tehnika 2017, 1,: 137-142. ISSN 2334-7368

\section{REZIME}

\section{PRAĆENJE KVALITETA INDUSTRIJSKIH OTPADNIH VODA U INSTITUCIJAMA JAVNOG ZDRAVLJA U SRBIJI}

Dispozicija otpadnih voda prepoznata je od strane sektora javnog zdravlja, zbog svog negativnog učinka na životnu sredinu i zdravlje. Rad je studija preseka, za period monitoringa 2015-2017. Ključni cilj je prezentovanje obima učešća institucija javnog zdravlja u monitoringu kvaliteta industrijskih otpadnih voda. Uzorci otpadnih voda uzeti su u pogonima iz oblasti: hemijske, prehrambene, rudarsko-metalurške $i$ energetske, kao i saobraćajne, uslužne, drvno-prerađivačke i tekstilne delatnosti. Kao instrument istraživanja korišćena je baza podataka Instituta za javno zdravlje Srbije, ažurirana na godišnjem nivou sa podacima iz lokalnih zavoda za javno zdravlje, čije laboratorije analiziraju uzorke otpadnih voda, na tržišnom principu. Sumirajući rezultate dobijene u sve tri uzastopne godine, ukupno je analizirano 13392 uzorka otpadnih voda, od kojih 44.79\% (5999) nije bilo usklađeno sa važećom nacionalnom legislativom. Opserviranjem dinamike prečišćavanja otpadnih voda poreklom iz pogona čiji su uzorci analizirani, vidna je nedovoljna primena ovog procesa. U sve tri godine praćenja, nedostatak prečišćavanja otpadnih voda pre uliva u konačni recipijent nadmašuje 50\% pogona, a što se može povezati sa činjenicom da najdominantnije opterećenje uzoraka predstavljaju: suspendovane $i$ sedimentne materije, hemijska potrošnja kiseonika, biološka potrošnja kiseonika, amonijak, masti $i$ ulja, itd. Činjenica da se u većini slučajeva dispozicija otpadnih voda vrši direktno u u prirodne vodotokove dodatno ukazuje na postojanje kontinuirano prisutnog rizika po životnu sredinu i zdravlje.

Ključne reči: industrijske otpadne vode, uzorci, zavodi za javno zdravlje, prečišćavanje 